\title{
NUMERICAL AND EXPERIMENTAL RESEARCH ON DELAMINATION OF GLULAM ELEMENTS
}

\author{
B. KAWECKI ${ }^{1}$, J. PODGÓRSKI²
}

\begin{abstract}
The paper presents numerical and experimental research on glulam delamination in a double lap connection with predominant shear stresses. Laboratory tests and wide literature survey enabled to determine timber and glue joint parameters. Cohesive zone theory, generally used for epoxy matrix and fiber reinforced composites, was adopted to modelling glue layer delamination in glulam elements. Numerical models were validated with laboratory tests.
\end{abstract}

Keywords: FEM, glulam, delamination, shear stress, laboratory testing

\section{INTRODUCTION}

Glued laminated timber is a material with many unique parameters for various applications. The most common are engineering constructions as roofs, skeleton buildings and bridges. Frequently its aesthetical features and forming simplicity, connected with high strength, gives a feasibility to create magnificent architectural objects. Glulam is composed of several precisely selected timber layers connected by glue joints. It leads to entire structure improvement. Unfortunately, one of the crucial disadvantages of multi-layer structures is an interfacial delamination phenomenon.

There are many recent publications about testing composites with epoxy resin matrices and glass, or carbon fibers in mode I [1,2] and in mode II [3, 4]. Papers concerning glue laminated timber

\footnotetext{
${ }^{1}$ MSc., Lublin University of Technology, Faculty of Civil Engineering and Architecture, ul. Nadbystrzycka 40, 20-618 Lublin, Poland, e-mail: b.kawecki@pollub.pl

${ }^{2}$ Prof., Lublin University of Technology, Faculty of Civil Engineering and Architecture, ul. Nadbystrzycka 40, 20-618 Lublin, Poland, e-mail: j.podgorski@pollub.pl
} 
delamination occurs in minority, comparing to other composite materials. The probable reasons are highly anisotropic wood parameters [5] and difficulties in glulam testing, or numerical modelling.

Approaches to describe the material damage in experimental tests were given in several publications. Shear strength in glulam for different timber types was examined in [6]. In the paper of Aicher and Ohnesorge [7] research on shear failure in glulam, in three and four point bending tests, was done. Interlaminar shear damage appeared in the half of examined samples. Investigation on delamination resistance and shear strength, in dependence on various wood species was conducted in [8]. Double lap shear test was done in [9]. There was used the basic shear stress calculation. State of the art clearly shows, that shear delamination, in experimental testing of glued laminated timber, is still scientifically important and not fully examined.

Due to development of the numerical methods in mechanics, arose a need to describe delamination and fracture phenomena more accurately. In the thesis [10] several configurations for adhesive joints in glue laminated timber were numerically modelled and experimentally tested. Paper [11] presented an approach for the numerical modelling of delamination in modified DCB test. Some study of the interlaminar fracture characterization, using image analysis, was performed in [12]. State of the art shows that development of the computational modelling of the glued laminated timber is still in progress.

\section{TIMBER PARAMETERS DETERMINATION}

To obtain elastic modules for the timber, compression test in two directions was done. There were prepared 8 samples in dimensions of $100 \times 100 \times 80 \mathrm{~mm}-$ presented in the Fig. 1 . They were cut from the same glulam beam delivered by the producer of certified elements. Larger knots, finger joints and another visible defects were eliminated to provide as homogenous material, as possible.

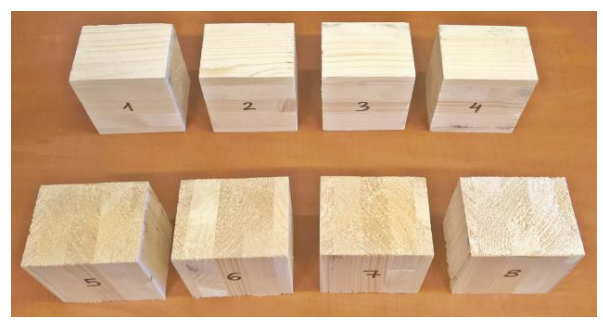

Fig. 1. Samples for the compression test 
For the test, there was used MTS 809 machine with additional extensometer mounted on the sample. Firstly $E_{l}$ modulus was tested, only in the elastic range. Consecutively, the sample was rotated in plane by 90 degrees and $E_{2}$ modulus was tested. Laboratory stand and tests results were presented in the Fig. 2.
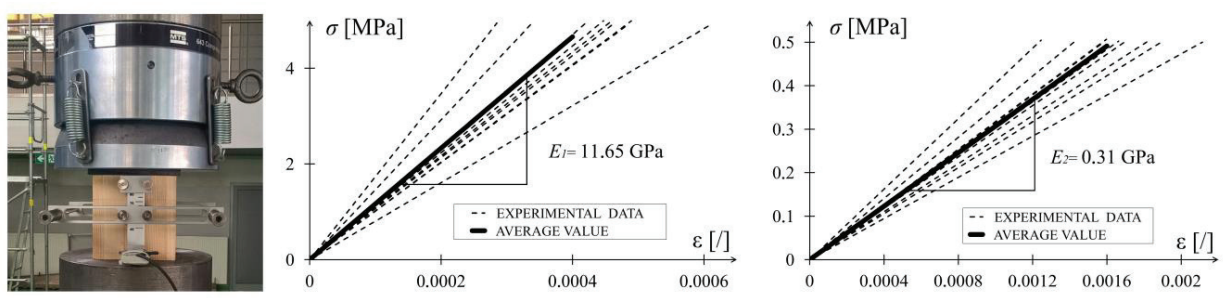

Fig. 2. Compression test - laboratory stand and elastic modules from laboratory tests

On the basis of the average elastic modules' values, material was classified to the GL24h class and shear modulus $G_{12}$ was assumed relating to the class. Poisson coefficient was determined through numerical modelling and iterating.

Next, there was prepared 2D FEM model of the compression test in Simulia Abaqus software. General model parameters and assumptions were presented in the Fig. 3.

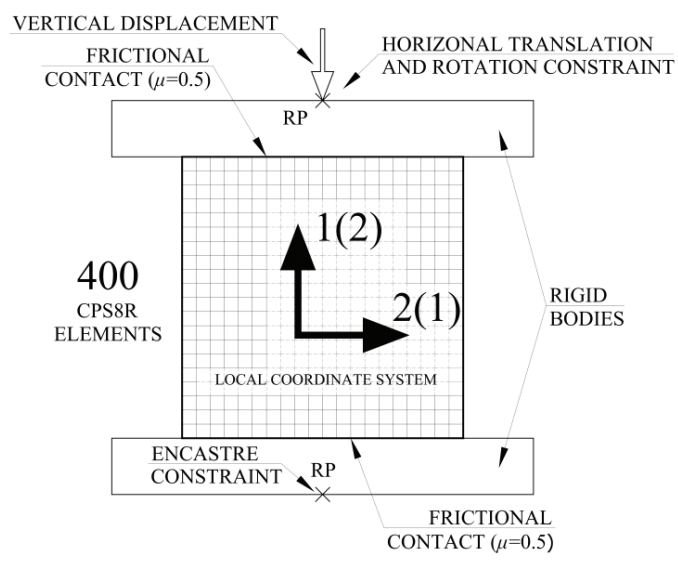

Fig. 3. Compression test - FEM model

Timber material was considered to be an orthotropic one. Constitutive law for a plane stress orthotropic material $[13,14]$ was defined by $(2.1)$ and presented in the Fig.4. 


$$
\left[\begin{array}{l}
\varepsilon_{11} \\
\varepsilon_{22} \\
\gamma_{12}
\end{array}\right]=\left[\begin{array}{ccc}
\frac{1}{E_{1}} & -\frac{v_{21}}{E_{2}} & 0 \\
-\frac{v_{12}}{E_{1}} & \frac{1}{E_{2}} & 0 \\
0 & 0 & \frac{1}{G_{12}}
\end{array}\right]\left[\begin{array}{c}
\sigma_{11} \\
\sigma_{22} \\
\tau_{12}
\end{array}\right]
$$

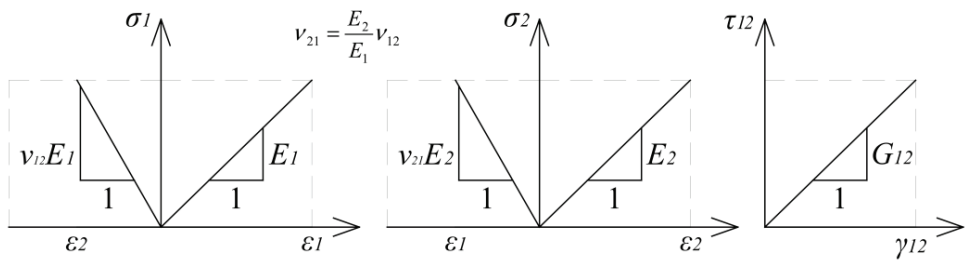

Fig. 4. Orthotropic constitutive law for plane stress

Elastic modules $E_{1}$ and $E_{2}$ are dependent on Poisson coefficients $v_{12}$ and $v_{21}=\frac{E_{2}}{E_{1}} v_{12}$, shear modulus $G_{12}$ is an independent material parameter.

Mesh and elements type were selected basing on the previous numerical tests for plane stress elements, described in the paper [15]. The type of the test and low load value, allowed to make an assumption, that planks were perfectly bonded. It lead to the simplification of the model and treating material as homogenous. Compression test was performed in two local coordinate system sets. The same order was kept, as it was done in the experiments. Poisson coefficient was executed through iteration from the interval $0.32-0.37$, as specified in the literature [16]. After several iterations, Poisson coefficient adequate to the laboratory tests was determined as $v_{12}=0.35$. Final timber parameters accepted for further analyses were given in the Tab. 1 .

Table 1. Timber parameters used in the numerical analyses

\begin{tabular}{|c|c|c|}
\hline Parameter & Denotation & Value \\
\hline Longitudinal Elastic Modulus & $E_{l}$ & $11.65 \mathrm{GPa}$ \\
\hline Transversal Elastic Modulus & $E_{2}$ & $0.31 \mathrm{GPa}$ \\
\hline Shear Modulus & $G_{12}$ & $0.69 \mathrm{GPa}$ \\
\hline Poisson Coefficient & $v_{12}$ & 0.35 \\
\hline Single Finite Element Size & - & $5 \times 5 \mathrm{~mm}$ \\
\hline
\end{tabular}




\section{GLUE PARAMETERS DETERMINATION}

Parameters for glue layer were determined basing on guidelines about multi-layer composites, available in the literature. Cohesive zone delamination model in mode I and mode II was described in many publications, including [17-19]. According to these papers and authors' analyses in publication [20], cohesive zone parameters should be defined as follows.

Penalty stiffness $(K)$ of the adhesive should meet the requirement:

$$
K=\alpha \frac{E_{1}}{h_{1}}
$$

where:

$\alpha=50$ (Turon's parameter)

$E_{1}$ - longitudinal elastic modulus of the timber

$h_{1}$ - the smallest thickness of bonded elements

Single cohesive element length $\left(l_{e}\right)$ should meet the requirements:

$$
l_{e} \leq \frac{l_{I c}}{N_{e}} \quad \text { and } \quad l_{e} \leq \frac{l_{I I c}}{N_{e}}
$$

Cohesive zone length $\left(l_{I c}, l_{I I C}\right)$ for each mode was determined as:

$$
l_{I c}=M E_{c} \frac{G_{I c}}{\sigma_{I c}{ }^{2}} \quad \text { and } \quad l_{I I c}=M G_{c} \frac{G_{I I c}}{\tau_{I I c}{ }^{2}}
$$

where:

$M=0.31$ (Irwin's theory parameter)

$E_{c}, G_{c}$ - isotropic glue parameters

$G_{I c}, G_{I I c}$ - energy release rate in Mode I and Mode II

$\sigma_{I c}, \tau_{I I c}$ - damage stress initiation value in Mode I and Mode II

Elastic modulus and Poisson coefficient for polyurethane glue was determined basing on [21, 22]. Shear modulus was calculated as for isotropic materials, using formula: 


$$
G_{c}=\frac{E_{c}}{2\left(1+v_{c}\right)}
$$

Because most of the parameters depends on laboratory test they were given in the Table 2, in the next paragraph.

\section{LABORATORY TESTS AND MODEL CALIBRATION}

Double lap shear test was performed on MTS 809 machine. Pattern of the test and the method of energy release rate calculation were presented in the Fig. 5.

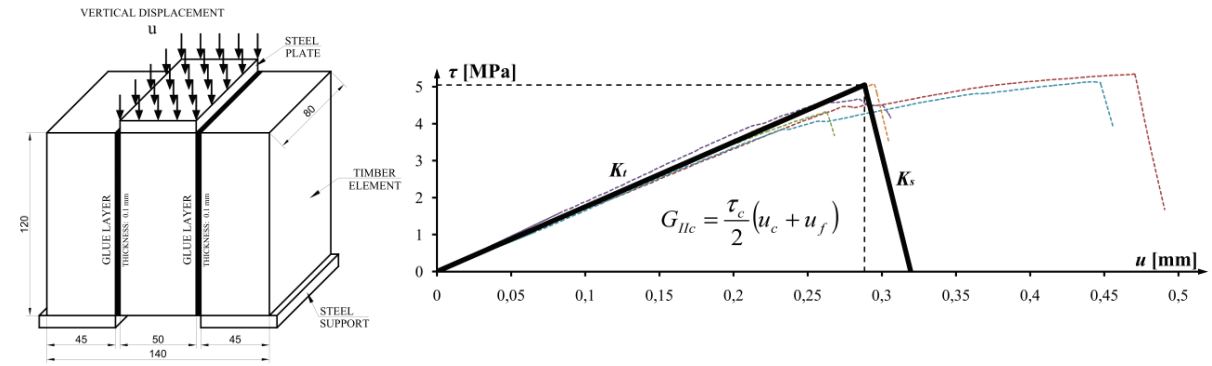

Fig. 5. Pattern of the double lap shear test and the method of energy release rate calculation

Experiments were carried out on 5 specimens in dimensions of $140 \times 120 \times 80 \mathrm{~mm}$. During the test, vertical displacement was controlled and vertical force was measured. As it was performed in $[8,9]$, shear stresses were calculated basing on the mechanical formula:

$$
\tau=\frac{P}{A_{v}}
$$

where:

$P$ - force obtained from testing machine

$A_{v}$ - shear area

Next step was fracture Mode II energy release rate calculation, basing on [23]. The method was shown in the Fig. 5. 
Damage initiation criterion was defined as:

$$
\frac{\tau_{x y}}{\tau_{I I c}}=1
$$

where:

$\tau_{x y}$ - shear stress calculated in the numerical model for a single finite element $\tau_{I I C}$ - shear stress value at the start of the element damage

Energy release rate, calculated using above principles, was applied to the FEM model. On the basis of the laboratory test results, the glue layer parameters were determined. Because only shear stresses were considered, single cohesive finite element length was calculated from mode II delamination formulas. All of glue line parameters were given in the Table 2.

Table 2. Glue parameters used in the numerical analyses

\begin{tabular}{|c|c|c|}
\hline Parameter & Denotation & Value \\
\hline Irwin's Theory Parameter & $M$ & 0.31 \\
\hline Penalty Stiffness & $K$ & $12.95 \mathrm{GPa} / \mathrm{mm}$ \\
\hline Damage Initiation Shear Stress & $\tau_{I l c}$ & $5.05 \mathrm{MPa}$ \\
\hline Fracture Energy & $G_{I I c}$ & $807 \mathrm{~J} / \mathrm{m} 2$ \\
\hline Elastic Modulus & $E$ & $1.2 \mathrm{GPa}$ \\
\hline Poisson Coefficient & $v$ & 0.45 \\
\hline Shear Modulus & $G$ & $0.414 \mathrm{GPa}$ \\
\hline Cohesive Zone Length & $l_{I I c}$ & $4.06 \mathrm{~mm}$ \\
\hline Number of Elements in Cohesive Zone & $N_{e}$ & 3 \\
\hline Maximal Single Finite Element Length & $l_{e}$ & $1.35 \mathrm{~mm}$ \\
\hline
\end{tabular}




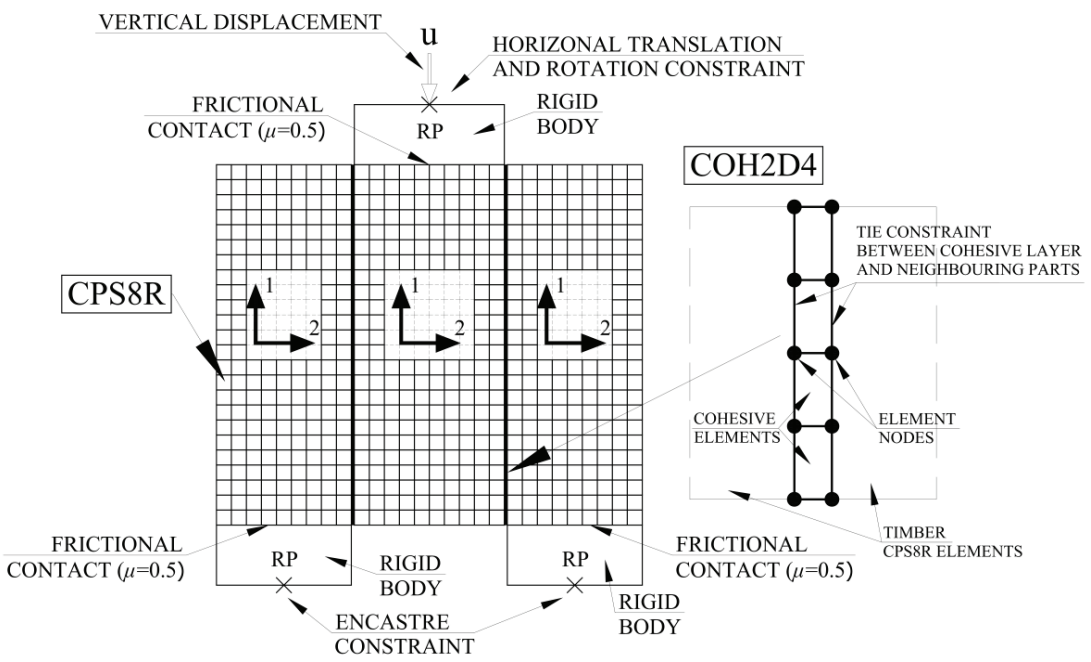

Fig. 6. Double lap shear test - FEM model details

Single cohesive element length was defined as $l_{e}=1.25 \mathrm{~mm}$ to provide proper elements distribution between timber element's nodes - four COH2D4 elements per one CPS8R element. Applied mesh was the same as in the compression test, shown in the Fig. 2. Mesh compatibility was necessary to eliminate any mesh reason disturbances in the timber material parameters. Mesh, boundary conditions and another model assumptions were described in the Fig. 6.

\section{RESULTS AND DISCUSSION}

When delamination process is taken into account, the analysed element's work may be divided into three stages:

- Stage I - before interface damage initiation criterion is met (when interface ensures perfect bonding)

- Stage II - while interface softening and fracture is in progress

- $\quad$ Stage III - when interface is fully fractured

Underneath, in the Fig. 7 and Fig. 8, there were presented Huber-Mises stress distribution and magnitude displacements, at the end of each stage. Representative examples show the complexity of stress and displacement distribution in the whole sample, when delamination occurs. 

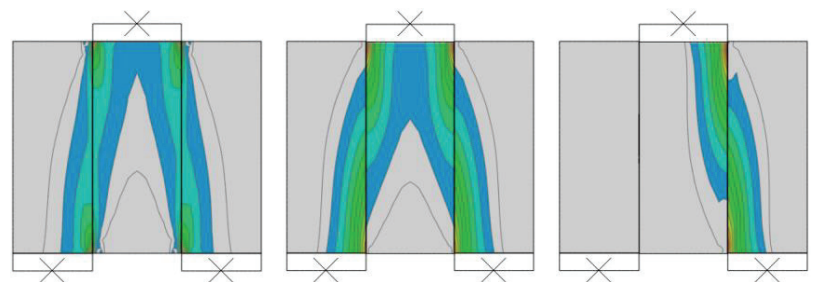

Fig. 7. Huber-Mises stress distribution in the sample - consecutively Stage I, II and III
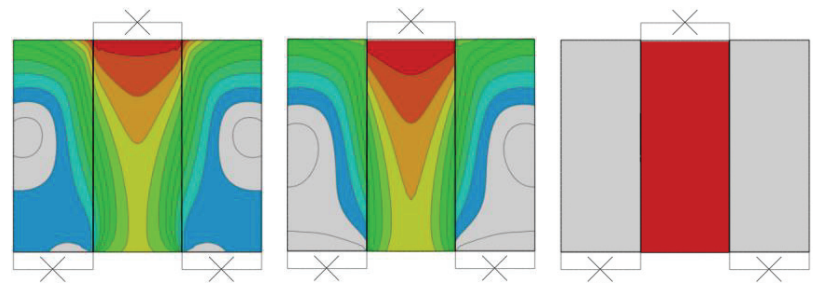

Fig. 8. Magnitude displacements distribution in the sample - consecutively Stage I, II and III

Glue layer fracture in the experimental tests turned out to be unsymmetrical. Samples after the test, with marked place of failure, were presented in the Fig. 9. The same phenomenon was observed in the numerical model. Despite model and mesh was symmetrical, asymmetry was achieved by applying non-linear effects such as contact and friction, which were taken into account in the FEM model.

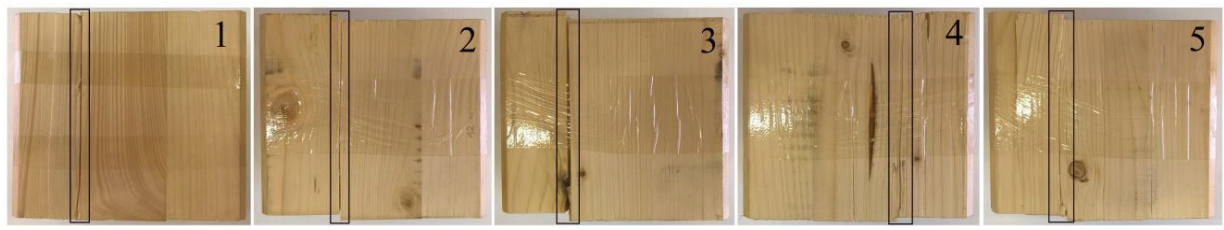

Fig. 9. Double lap shear samples after the test

Laboratory test stand and experimental results compared to FEM results were presented in the Fig. 10. 

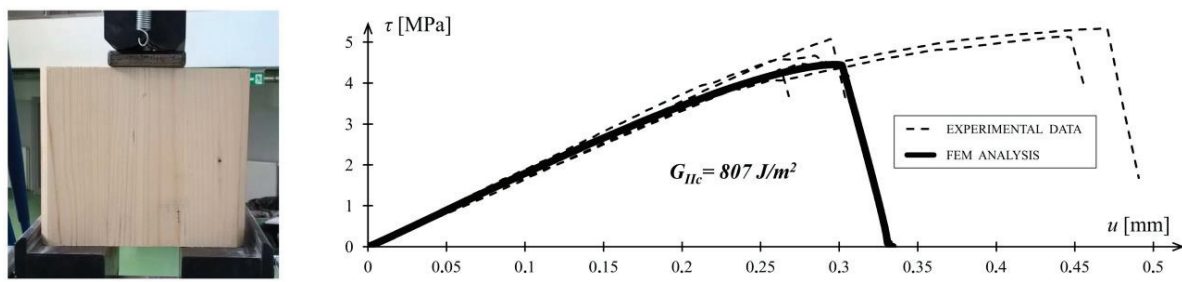

Fig. 10. Double lap shear test - laboratory stand and results

Comparing numerical results to the experimental research, it was visible similarity in the $\tau$ - $u$ relation. FEM model gave almost the same displacement at failure as the laboratory tests. For better understanding of the interface work, there were performed more accurate analyses of the damage initiation stress and energy release rate distribution through the glue joint length.

There were determined 13 points on the joint. In each point the $\tau$ - $u$ relation was plotted and area under the curve was calculated. Basing on that data, there were made the plots of relation between point on the joint and damage initiation stress, or energy release rate value (Fig. 11).
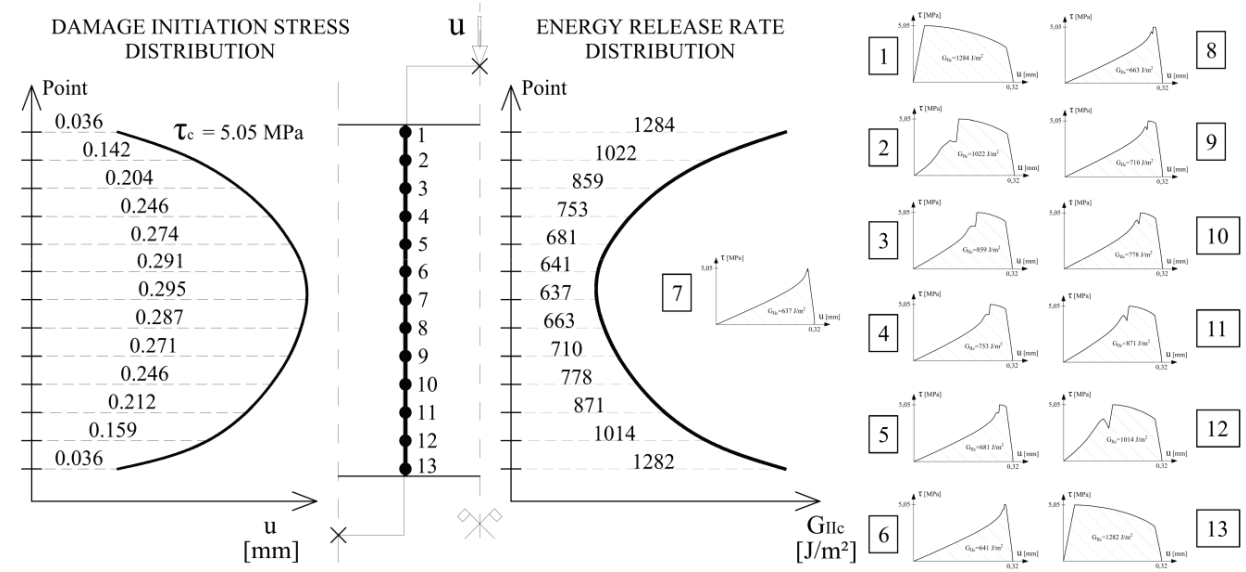

Fig. 11. Damage initiation stress and energy release rate distribution on the joint length

There was observed parabolic and almost symmetrical damage initiation stress and energy release rate distribution through the joint length. It was visible that stress state in the glulam joints was much more complicated, that it had been assumed at the beginning. There was stated the need of constant development of the numerical description of bonded connections work. 


\section{CONCLUSIONS}

The paper presented more complicated approach of numerical modelling double lap shear connections in glued laminated timber, than it was presented in currently accessible publications. Timber material was considered to be highly orthotropic and the cohesive joint was modelled on the basis of traction separation law. FEM simulation procedures of the interface layer behaviour were adopted from epoxy-carbon/glass composites, which was a relatively original idea. There was proposed supplementing laboratory tests with numerical simulations, in some cases, when laboratory tests require very complicated accessories. Numerical analyses showed that stress state in the glulam joints is much more complicated, than it was assumed in cited publications. There was stated the need of constant development of the numerical description of bonded connections work.

\section{REFERENCES}

1. V. A. Franklin, T. Christopher, "Fracture Energy Estimation of DCB Specimens Made of Glass/Epoxy: An Experimental Study", Advances in Materials Science and Engineering, 2013.

2. K. Kumar, S. Rao, N. Gopikrishna, "Evaluation of strain energy release rate of epoxy glass fibre laminate (mode - I)", International Education And Research Journal 3(1), 2017.

3. B. R. K. Blackman, A.J. Kinloch, M. Paraschi, "The determination of the mode II adhesive fracture resistance, GIIC, of structural adhesive joints: an effective crack length approach", In Engineering Fracture Mechanics 72 (6), pp. 877-897, 2005.

4. M. F. S. F. de Moura, R. D. S. G. Campilho, J. P. M. Gonçalves, "Pure mode II fracture characterization of composite bonded joints", In International Journal of Solids and Structures 46 (6), pp. 1589-1595, 2009.

5. N. T. Mascia, F. A. R. Lahr, "Remarks on orthotropic elastic models applied to wood", Materials Research 9(3), pp. 301-310, 2006.

6. G. Castro, F. Paganini, Holz Roh Werkst 61 291, 2003.

7. S. Aicher, D. Ohnesorge, European Journal of Wood and Wood Products 69 143, 2011.

8. Y. Jiang, J. Schaffrath, M. Knorz, S. Winter, J. W. G. Van de Kuilen, "Applicability of various wood species in glued laminated timber: Parameter study on delamination resistance and shear strength", WCTE 2014: Proceedings of the World Conference on Timber Engineering, 2014.

9. D. H. de Almeida, R. S. Cavalheiro, L. B. de Macêdo, C. C. Neto, A. L. Christoforo, C. C. Junior, F. A. R. Lahr, "Evaluation of Quality in the Adhesion of Glued Laminated Timber (Glulam) of Paricá and Lyptus Wood Species", International Journal of Materials Engineering 4(3), pp. 114-118, 2014.

10. E. Serrano, "Adhesive Joints in Timber Engineering. Modelling and Testing of Fracture Properties Division of Structural Mechanics", Lund University, 2000.

11. S. Fortino, G. Zagari, A. L. Mendicino, G. Dill-Langer, "A simple approach for FEM simulation of Mode I cohesive crack growth in glued laminated timber under short-term loading", Rakenteiden Mekaniikka (Journal of Structural Mechanics) 45(1), pp. 1-20, 2012.

12. V. Z. Wang, J. D. Ginger, K. Narayan, "Intralaminar and interlaminar fracture characterization in gluedlaminated timber members using image analysis", In Engineering Fracture Mechanics 82, pp. 73-84, 2012.

13. S. G. Lekhnitskii, "Theory of Elasticity of an Anisotropic Elastic Body", Mir Publishers, 1981.

14. R. M. Jones, Mechanics of Composite Materials. Second Edition, pp. 55-73, 1999. 
15. B. Kawecki, J. Podgórski, "Numerical results quality in dependence on Abaqus plane stress elements type in big displacements compression test" Applied Computer Science, vol. 13, no. 4, pp. $56-64$ (2017). doi: 10.23743/acs2017-29

16. P. P. Gillis, Wood Science and Technology 6: 138, 1972.

17. K. Song, C. G. Davila, C. A. Rose, "Guidelines and Parameter Selection for the Simulation of Progressive Delamination", ABAQUS Users' Conference, 2007.

18. M. J. Lee, T. M. Cho, W. S. Kim, B. C. Lee, J. J. Lee, "Determination of cohesive parameters for a mixed-mode cohesive zone model", In International Journal of Adhesion and Adhesives 30 (5), pp. 322-328, 2010.

19. M. Moslemi, M. Khoshravan, "Cohesive Zone Parameters Selection for Mode-I Prediction of Interfacial Delamination", Strojniški vestnik - Journal of Mechanical Engineering 61(9), pp. 507-516, 2015.

20. B. Kawecki, J. Podgórski, "Numerical model of glulam beam delamination in dependence on cohesive strength" AIP Conference Proceedings 1922, 050005 (2018). doi: https://doi.org/10.1063/1.5019059

21. S. Clauß, J. Gabriel, A. Karbach, et al, "Influence of the adhesive formulation on the mechanical properties and bonding performance of polyurethane prepolymers", Holzforschung 65(6), pp. 835-844, 2011.

22. O. Kläusler, S. Clauß, L. Lübke, J. Trachsel, P. Niemz, "Influence of moisture on stress-strain behaviour of adhesives used for structural bonding of wood", In International Journal of Adhesion and Adhesives 44, pp. 57 $65,2013$.

23. Z. Mróz, K. P. Mróz, "Analysis of delamination and damage growth in joined bi-layer systems", In Geomechanics for Energy and the Environment 4, pp. 4-28, 2015.

\section{LIST OF FIGURES AND TABLES:}

Fig. 1. Samples for the compression test

Rys. 1. Próbki do badania ściskania

Fig. 2. Compression test - laboratory stand and elastic modules from laboratory tests

Rys. 2. Badanie ściskania - stanowisko laboratoryjne i moduły sprężystości z badań laboratoryjnych

Fig. 3. Compression test - FEM model

Rys. 3. Badanie ściskanie - model MES

Fig. 4. Orthotropic constitutive law for plane stress

Rys. 4. Ortotropowe prawo konstytutywne dla płaskiego stanu naprężeń

Fig. 5. Pattern of the double lap shear test and the method of energy release rate calculation

Rys. 5. Schemat badania dwu-zakładkowego połączenia ścinanego i metoda obliczania współczynnika uwalniania energii

Fig. 6. Double lap shear test - FEM model details

Rys. 6. Szczegóły modelu MES dwu-zakładkowego połączenia ścinanego

Fig. 7. Huber-Mises stress distribution in the sample - consecutively Stage I, II and III

Rys. 7. Rozkład naprężeń zredukowanych Hubera-Misesa w próbce - kolejno Etap I, II i III

Fig. 8. Magnitude displacements distribution in the sample - consecutively Stage I, II and III 
Rys. 8. Rozkład przemieszczeń wypadkowych w próbce - kolejno Etap I, II i III

Fig. 9. Double lap shear samples after the test

Rys. 9. Próbki po wykonaniu próby ścinania

Fig. 10. Double lap shear test - laboratory stand and results

Rys. 10. Badanie ścinania dwu-zakładkowego - stanowisko laboratoryjne i wyniki

Fig. 11. Damage initiation stress and energy release rate distribution on the joint length

Rys. 11. Rozkłady naprężeń inicjujących pękanie i współczynnika uwalniania energii na długości spoiny

Tab. 1. Timber parameters used in the numerical analyses

Tab. 1. Parametry drewna wykorzystane w analizach numerycznych

Tab. 2. Glue parameters used in the numerical analyses

Tab. 2. Parametry kleju wykorzystane w analizach numerycznych 


\title{
NUMERYCZNE I DOŚWIADCZALNE BADANIA DELAMINACJI ELEMENTÓW Z DREWNA KLEJONEGO
}

\author{
Slowa kluczowe: MES, glulam, delaminacja, naprężenia styczne - ścinanie, badania laboratoryjne
}

\section{STRESZCZENIE:}

Drewno klejone jest materiałem o wielu unikalnych parametrach i zastosowaniach. Powszechnie znane są konstrukcje inżynierskie, takie jak dachy, budynki szkieletowe czy mosty, wykonane z tego materiału. Często jego walory estetyczne i łatwość formowania, połączone $\mathrm{z}$ dużą wytrzymałością, dają możliwość tworzenia różnorodnych obiektów architektonicznych. Element typu glulam złożony jest z kilku odpowiednio wyselekcjonowanych warstw drewna, połączonych klejem. Prowadzi to do polepszenia parametrów całego elementu. Niestety, jedną z podstawowych wad wielowarstwowych struktur jest zjawisko ich rozwarstwiania się. W literaturze dostępnych jest wiele publikacji dotyczący badania delaminacji w kompozytach z matrycą epoksydową i włóknami szklanymi lub węglowymi. Niewiele jest natomiast artykułów podejmujących ten temat w drewnie klejonym. Może być to spowodowane wysoką anizotropią drewna i trudnościami w badaniu laboratoryjnym lub modelowaniu numerycznym takich elementów.

Próby opisu zniszczenia materiału w badaniach laboratoryjnych zostały opisane w kilku publikacjach. Rozważano w nich wytrzymałość na ścinanie dla różnych gatunków drewna w próbach zginania trój- i cztero-punktowego oraz w próbie ścinania dwu-zakładkowego, stosując podstawowe sposoby obliczania naprężeń stycznych. Przeprowadzony przegląd literatury potwierdził, że badania laboratoryjne drewna klejonego są tematem aktualnym i wymagającym dalszego rozwijania.

$\mathrm{Z}$ uwagi na postęp w metodach komputerowych dotyczących modelowania numerycznego zagadnień mechaniki, powstała potrzeba dokładniejszego opisania delaminacji i procesów zniszczenia występujących w drewnie klejonym. Przegląd literatury pod względem komputerowego modelowania powyższych procesów również potwierdził aktualność i potrzebę dalszego rozwijania tego zagadnienia.

W artykule podjęto temat komputerowego modelowania połączenia dwu-zakładkowego w drewnie klejonym. Dokonano dwuetapowej kalibracji modelu numerycznego na podstawie badań laboratoryjnych. Próbki wykonano poprzez pocięcie belek z drewna klejonego, pomijając większe sęki lub połączenia lameli w celu uzyskania możliwie jednorodnego materiału. Zarówno w przypadku badań laboratoryjnych jak i w analizach numerycznych sterowano przyrostem przemieszczenia mierząc wartość siły pionowej.

$\mathrm{W}$ pierwszym etapie należało określić parametry drewna niezbędne do zastosowania materiału ortotropowego $\mathrm{w}$ analizie dwuwymiarowej. W tym celu wykonano badania ściskania na próbkach prostopadłościennych w dwóch wzajemnie prostopadłych kierunkach. Wynikiem tych badań był podłużny oraz poprzeczny moduł sprężystości. Współczynnik Poissona wyznaczono w drodze iteracji na podstawie modelu numerycznego, wprowadzając otrzymane wcześniej moduły sprężystości i ściskając element w taki sam sposób jak w badaniach laboratoryjnych. Moduł ścinania, który jest parametrem niezależnym od modułów sprężystości w przypadku materiału ortotropowego, przyjęto jako normowy, na podstawie kwalifikacji drewna do odpowiedniej klasy. Do wykonania modelu MES posłużono się programem Simulia Abaqus. Wykorzystane elementy skończone, które dokładnie sprawdzono pod względem możliwości ich zastosowania oraz dokładności otrzymywanych wyników.

W drugim etapie należało określić parametry warstwy kleju niezbędne do zastosowania elementów kohezyjnych. Badania laboratoryjne modułu sprężystości podłużnej i poprzecznej kleju poliuretanowego wykorzystanego przy produkcji 
elementów odnaleziono w literaturze. Następnie wykonano badania ścinania połączenia dwu-zakładkowego i wyznaczono zależność naprężenie styczne - przemieszczenie. Na podstawie pola powierzchni pod wykresem możliwe było obliczenie energii pękania $\mathrm{w}$ drugim schemacie zniszczenia. Znając naprężenie styczne inicjujące proces zniszczenia, energię pękania oraz moduły sprężystości podłużnej i poprzecznej kleju, określono odpowiednią długość strefy kohezji oraz maksymalne wymiary elementów kohezyjnych.

Wszystkie dobrane parametry wprowadzono do modelu numerycznego połączenia dwu-zakładkowego. Dla elementów drewnianych zastosowano takie same wymiary jak w pierwszym etapie w celu uniknięcia zaburzeń powodowanych przez zmianę gęstości siatki.

Po wykonaniu analizy numerycznej stwierdzono, że zastosowane parametry pozwoliły osiągnąć zadowalającą zbieżność wyników z badaniami laboratoryjnymi oraz podobne formy zniszczenia elementów. W celu dokładniejszego opisania zjawisk zachodzących w połączeniu, wyznaczono rozkłady naprężeń inicjujących pękanie i energii pękania na długości spoiny. Na podstawie powyższych zależności zaobserwowano, że zarówno rozkład naprężeń inicjujących, jak i rozkład energii pękania są paraboliczne i zdecydowanie bardziej skomplikowane niż było to rozpatrywane w cytowanych publikacjach. Na koniec stwierdzono potrzebę rozwijania dokładniejszego sposobu numerycznego modelowania takich połączeń. 